\title{
HEGEL E A RELIGIÃO COMO O SEGUNDO MOMENTO DA MARCHA DO ESPÍRITO
}

\author{
Hegel and Religion as the Second Moment of the Spirit's Itinerary
}

Rogério Miranda de Almeida ${ }^{1}$

Guilherme Costa Fernandes ${ }^{2}$

\begin{abstract}
RESUMO: Estas reflexões têm como objetivo principal ressaltar a concepção hegeliana da religião no que diz respeito, mais especificamente, à religião como o segundo momento da marcha do Espírito Absoluto. Como se sabe, tanto o sistema hegeliano como um todo, quanto a sua concepção da religião em particular são por demais amplos, nuançados e suscetíveis das mais diversas interpretações, dada a própria evolução e as transformações pelas quais passou o seu pensamento. Esta é razão pela qual, considerando os limites formais deste artigo, nós nos ativemos a tão somente fazer relevar, de maneira descritiva e analítica, a questão da religião tal como Hegel a apresenta na Fenomenologia do Espírito.
\end{abstract}

PALAVRAS-CHAVE: Hegel; Religião; Espírito Absoluto; Saber Absoluto; Suprassunção.

ABSTRACT: These reflections aim at emphasizing the Hegelian conception of religion regarding, more specifically, the religion as the second moment of the itinerary of the Absolut Spirit. As it is known, both the Hegelian system as a whole and his conception of religion in particular are very extensive, nuanced and susceptible of the most varied interpretations. This is given, principally, to the evolution and the transformations through which his thought unfolds itself. This is the reason why, considering the formal limits of this paper, we limited ourselves only to underscore, in a descriptive and analytical way, the question of religion such as Hegel presents it in the Phenomenology of Spirit.

KEYWORDS: Hegel; Religion; Absolut Spirit; Absolut Knowledge; Overcoming.

De forma geral, na filosofia hegeliana a religião se apresenta como o segundo momento da marcha do Espírito Absoluto, pois nela, assim como na arte e no Saber Absoluto, o Espírito se sabe a si mesmo e submete a si tanto o seu mundo objetivo como

\footnotetext{
${ }^{1}$ Doutor em filosofia pela Universidade de Metz e em teologia pela Universidade de Estrasburgo, professor emérito do programa de pós-graduação em filosofia da Pontifícia Universidade Católica do Paraná (PUCPR), de filosofia na Faculdade São Basílio Magno (FASBAM) e de teologia sistemática no Claretiano - Centro Universitário. E-mail: r.mirandaalmeida@gmail.com

${ }^{2}$ Bacharel em filosofia pela Faculdade São Basílio Magno (FASBAM) e graduando em teologia pelo Claretiano - Centro Universitário. E-mail: guilhermecf45@gmail.com
} 
suas representações e determinações. Isto se dá numa espécie de consciência-que-estájunto-de-si ou de espírito universal que abrange toda a essência e toda a efetividade (Wirklichkeit). Na Fenomenologia do Espírito e, mais especificamente, no capítulo VII, Hegel desenvolve o caminho da religião no processo do Espírito Absoluto; ele mostra também sua evolução na história através das mais variadas manifestações religiosas da humanidade que culminam no Saber Absoluto. Esta última etapa é para o filósofo a mais perfeita expressão do Espírito Absoluto.

Ora, logo no início do capítulo VII da Fenomenologia - capítulo significativamente intitulado A religião -, Hegel afirma que a religião também se apresenta como a consciência da essência absoluta em geral ${ }^{3}$. E, de fato, ao longo desta obra é possível detectar, no desenrolar do Espírito, a presença de uma consciência da essência absoluta naquelas figuras e naqueles momentos que se manifestam, por exemplo, no "suprassensível", no “interior", na "consciência infeliz" e na dependência e independência da consciência-de-si e para-si. Pode-se, pois, deduzir que todas essas fases da marcha do Espírito em direção à esfera da religião são momentos em que a consciência já possui consciência do Absoluto, do Universal, do Infinito e do Imutável. Todavia, nessas formas anteriores ao momento propriamente dito da religião, a essência absoluta ainda não aparecia em si e para si mesma, como ela o fará de maneira explícita nos estágios do Espírito Absoluto. É lícito, porém, afirmar que, na esfera da religião, a essência absoluta já tem consciência de si através do Espírito.

Entretanto, o âmbito da religião, por mais evoluído que seja, na marcha do Espírito, ainda está limitado à dualidade entre os dois mundos: o mutável e o imutável. Hegel acentua que esses dois mundos são um só. Certo, a consciência mutável sempre considera o imutável, ou aquilo que é universal, fora dela, numa esfera inatingível, quando, na verdade, ela está dentro de si, formando duas realidades que co-incidem uma com a outra. Mas isto só ocorre quando o Espírito, consciente de si, torna-se efetivo, isto é, torna-se objeto da consciência através do puro conceito, no saber absoluto, desprovido de todo véu. Na verdade, somente o Espírito consciente de si pode manifestar-se de modo pleno, pois só ele satisfaz o paradoxo de ser um objeto da consciência e, ao mesmo tempo, uma efetividade livre e independente. Neste sentido, na religião ainda não houve a superação

\footnotetext{
${ }^{3}$ Cf. HEGEL, Georg Wilhelm Friedrich. Phänomenologie des Geistes. Werke 3. Frankfurt am Main: Suhrkamp, 1986, p. 495. Veja também, com relação à concepção hegeliana da religião: HEGEL, G. W. F. Frühe Schriften. Werke 1. Frankfurt am Main: Suhrkamp, 1986; Enzyklopädie der philosophischen Wissenschaften. Werke 10, III. Frankfurt am Main: Suhrkamp, 1986; Vorlesungen über die Philosophie der Religion. Werke 16, 17, I-II. Frankfurt am Main: Suhrkamp, 1986.
} 
da diferença entre o Espírito efetivo e o Espírito Absoluto. Ela ainda é um momento imediato do Espírito Absoluto e, justamente por isso, toma como essência de sua constituição e seguimento a consciência-de-si da essência absoluta, que abarca em si e para si toda a realidade e verdade. No entanto, ela age como consciência à medida que faz dessa consciência-de-si um objeto, um Ser-outro, diferente de si e que, por conseguinte, se revela inatingível em sua plenitude. Certo, ela apreende o Espírito de um modo imediato e o representa na imagem de Ser, de sorte que o Espírito não é ainda abarcado em sua essência, como unidade e identidade com a realidade. Não obstante, ao tornar-se religião da arte, deixando para trás a religião natural, a consciência efetuou um passo a mais. Como observa Alexandre Kojève, o homem agora fala. Melhor ainda, o deus assemelha-se ao homem, a forma concreta (Gestalt) divina torna-se consciência, na medida em que ela toma uma aparência humana pelo trabalho. O homem tornou-se assim um trabalhador espiritual, ou intelectual (geistiger Arbeiter). O "trabalhador intelectual" põe-se a falar de si mesmo acreditando, no entanto, que está a falar dos deuses. ${ }^{4}$ Portanto, na consciência-de-si da alma religiosa, o universal, por estar unido ao particular humano, é espiritual e obra do pensamento, ou da consciência. Contudo, pelo fato de o homem ainda não o reconhecer como obra sua, ou melhor, por não identificar esta obra como um produto de sua própria ação, não é dado a este Espírito um caráter puramente humano, na medida em que, como Deus, o Espírito extrapola o ser humano na sua imobilidade e imutabilidade. Efetivamente, este Deus se apresenta como uma forma determinada, fixa, estável e dada para sempre. Foi, portanto, a partir dessa realidade, ao longo da história da humanidade e da construção das civilizações, que cada religião foi sendo produzida pelo homem de acordo com suas especificidades, mas apresentando todas, cada uma a seu modo, esse Espírito como seu Deus.

Ora, este movimento do vir-a-ser da religião se manifesta de acordo com suas figuras e representações e os seus momentos culminam no Saber Absoluto, que é o último momento do Espírito Absoluto. Mas em que consistem esses momentos? Eles se desenrolam da seguinte maneira: primeiro momento, a religião imediata, natural, cuja essência absoluta se traduz como objeto na figura da natureza; segundo momento, a religião da arte, em que a essência absoluta é objeto como Si por meio da produção da consciência humana que, ao produzir-se, contempla no seu objeto criado o seu agir e o seu $\mathrm{Si}$; o terceiro momento se dá, finalmente, como religião revelada, que explicita a

\footnotetext{
${ }^{4}$ Cf. KOJÈVE, Alexandre. Introduction à la lecture de Hegel. Paris: Gallimard, 1947, p. 241.
} 
essência absoluta como ela é em-si e para-si. Comecemos então pelo primeiro momento: a religião natural.

\section{A religião natural}

O primeiro momento de efetividade do Espírito que tem consciência de si mesmo na religião é, segundo Hegel, a religião como imediata, ou seja, natural, haja vista que o Espírito se reconhece como seu próprio objeto numa representação da natureza, alheia e distinta vis-à-vis do homem. ${ }^{5}$

$\mathrm{Na}$ religião natural, encontramos, pois, a essência assumida pela consciência-de-si como um ser imediato, totalmente dado, como uma imediatidade sensível que pode ser vista, tocada e sentida pelas forças imanentes da natureza. Isto significa que a consciência religiosa nesse estágio da religião diviniza os objetos naturais, atribuindo-lhes o caráter de substância primordial da qual e pela qual toda a realidade provém. Neste sentido, as divindades da religião natural não estão mediadas pelo pensamento humano e não se identificam com o espírito humano. Ela se apresenta antes como a forma mais imediata pela qual a essência absoluta tem consciência de si através das determinadas figuras naturais. Esta é a razão pela qual as divindades são representadas pelas imagens da luz, das plantas, dos animais e dos objetos construídos por artesões que ainda não estão imbuídos do reflexo da mediação do espírito humano que projeta o seu Si naquilo que produz. ${ }^{6}$ Sem embargo, mesmo se apresentando de forma imediata, sem reflexão, a natureza já se encontra de certo modo superada, pois o Espírito, neste estágio da religião, começa a encontrar-se a si mesmo em uma obra, em um objeto. ${ }^{7}$

Num primeiro momento, como primeira das religiões naturais, encontramos a religião da luminosidade. Ela é a religião mais imediata, pois representa a essência divina, o Absoluto, como luz. Efetivamente, nela o Espírito, que se reconhece a si mesmo, surge como uma aurora luminosa do meio da escuridão, a partir da qual passa a preencher todas as coisas com emanações de sua luz criadora. Historicamente, Hegel se refere aqui à religião dos persas, fundada por Zoroastro. ${ }^{8}$

\footnotetext{
${ }^{5}$ Cf. HEGEL, Georg Wilhelm Friedrich. Fenomenologia do Espírito. 2. ed. Petrópolis: Vozes, 1993, p. 149.

${ }^{6}$ Cf. CALDAT, Gilberto de Melo. A Religião na Fenomenologia do Espirito de Hegel. Florianópolis: Universidade Federal de Santa Catarina, 2013, p. 87.

${ }^{7}$ Cf. HYPPOLITE, Jean. Gênesis y estrutura de la Fenomenologia del Espíritu de Hegel. Barcelona: Península, 1974, p. 493.

${ }^{8}$ Cf. MENESES, Paulo. Para ler a Fenomenologia do Espírito. São Paulo: Loyola, 1985, p. 175.
} 
Este Ser-Outro mais universal é, imediatamente para o Eu, o preenchimento e a permeação de tudo o que se movimenta, isto é, de todo o pensar e de toda a realidade efetiva, apresentando-se num símbolo que condiz mais com a certeza sensível no processo da consciência. Ela se encontra aqui como a figura de um Senhor: o Si se sente absorto pela grandeza majestosa de seu objeto assumido como sua essência. É uma substancialidade sem forma que sustenta e dá "força" a todas as criaturas determinadas. No entanto, essa representação não carrega consigo nenhum desenvolvimento reflexivo do $\mathrm{Si}$, na medida em que ela é ainda extrema abstração, ou seja, um universal ligado à natureza, mas sem nenhum tipo de determinidade. Nela não existem indivíduos, ou deuses personificados, pois nela tudo se encontra subsumido. Sua única forma de determinação são os seus atributos que, como figuras passageiras, não possuem um caráter independente, mas só se dão como nomes daquilo que Hegel chama de Uno primordial. ${ }^{9}$

É preciso, portanto, dar uma consistência a essas figuras instáveis absortas na luz, e somente o Espírito, que se reconhece na forma de Si, consegue realizar tal proeza. Eis por que, no processo dialético, essa forma mais abstrata de religião vai se determinando. Origina-se uma outra forma de religião natural, como se a essência luminosa fosse superada para dar gênese a um número variado de figuras superadas que cumpririam o mesmo papel. Ela é uma religião das plantas e dos animais na medida em que a essência absoluta é representada por seres viventes, presentes na natureza.

De fato, na religião das plantas e dos animais, é o Espírito quem determina a imediatez anteriormente citada, desdobrando-a em uma multiplicidade de seres vivos. É a religião da percepção natural, que também realiza a difusão da unidade numa pluralidade e pela qual o Espírito - segundo Hegel - se dispersa na variedade inumerável de espíritos "mais fracos e mais fortes, mais ricos e mais pobres". ${ }^{10}$

No começo desse movimento da religião natural, convém ressaltar a presença pacífica e passiva da religião das plantas e das flores. Trata-se de uma religião impoluta e voltada para a contemplação, porquanto os seus deuses, representados pelos vegetais, não possuem relação entre si. Mas esta forma pacífica de religião natural deverá deixar-se suprassumir por um outro momento, pois ela dará espaço à altercação e ao combate mortal da religião dos animais. ${ }^{11}$

\footnotetext{
${ }^{9}$ Cf. HEGEL, op. cit., v. 2., 1993, p. 152.

${ }^{10}$ HEGEL, op. cit., v. 2., 1993, p. 153.

${ }^{11}$ Cf. MENESES, op. cit., 1985, p. 176.
} 
Com efeito, a religião dos animais, com seus inúmeros sacrifícios sangrentos de expiação, corresponde a um reflexo do próprio Espírito efetivo, na medida em que passam a existir inúmeras guerras entre as civilizações. Neste sentido, cada povo hostil contempla a sua essência num tipo de animal e se torna semelhante a ele. Segundo Hegel, essa religião é a expressão de um espírito disperso em uma multidão de espíritos de povos, solitários e dissociados, que em seu ódio lutam até a morte. É uma religião que sobrevive do ódio dos deuses e do ódio entre tribos. Todavia, esse ódio se esgota e desgasta a determinidade do puro ser-para-si negativo. Consequentemente, através dessa nova realidade o Espírito entra em uma outra figura: a religião do artesão. ${ }^{12}$

De fato, neste terceiro movimento da religião natural encontramos a figura do artesão, ou do Espírito que se manifesta como artesão: trata-se de um tipo de religião na qual o homem passa a produzir o objeto ao qual prestará culto. A religião que possui a presença do artesão é aquela que se caracteriza por ter a figura do objeto produzido pelo $\mathrm{Si}$, na medida em que o $\mathrm{Si}$ mesmo se produz nesse objeto, permitindo assim o seu reconhecimento de si, o seu autoconsumir-se, o seu fazer-se coisa, em suma, a sua projeção. ${ }^{13}$ Ora, mesmo o artesão, produzindo-se a si mesmo como figura ou objeto, ainda não apreendeu o pensamento de Si em sua obra, ele é, como observa Hegel, um trabalhador instintivo, semelhante às abelhas que constroem os seus favos. ${ }^{14}$

$\mathrm{O}$ artesão aqui possui um caráter muito mais elevado do que o das divindades animalescas, que se dilaceram simultaneamente e combatem entre si. Ao invés de ser negativa e destrutiva como na religião dos animais, a atitude do artesão é mais positiva, pacífica e construtiva. É que, neste momento, o Espírito já começa a superar, mesmo que ainda de forma visivelmente imediata, o em-si imediato e o para-si abstrato. Em outros termos, a essência absoluta determinada pela consciência não é somente suprassumida e aceita, mas ela se torna também externalizada na figura de um objeto, porquanto ela produz por ela mesma a sua representação. ${ }^{15}$

Num primeiro passo, o artesão deposita em sua obra as formas mais abstratas que transformam a natureza que lhe é dada, construindo os cristais das pirâmides e dos obeliscos com as mais simples combinações de linhas retas, que eliminam de certa forma a incomensurabilidade das linhas curvas. ${ }^{16}$ Contudo, mesmo com esse rigor da

\footnotetext{
${ }^{12}$ Cf. HEGEL, op. cit., v. 2., 1993, p. 153.

${ }^{13}$ Cf. MENESES, op. cit., 1985, p. 176.

${ }^{14}$ Cf. HEGEL, op. cit., v. 2, 1993, p. 154.

${ }^{15}$ Cf. MENESES, op. cit., 1985, p. 176.

${ }^{16}$ Cf. HEGEL, op. cit., v. 2., 1993, p. 154.
} 
inteligibilidade formal já presente no trabalho artesanal, ele ainda não manifesta a presença de uma significação espiritual naquilo que produz como representação da essência. Essa significação sempre está nesse tipo de religião como algo diferente, estranho ou distinto em relação ao que foi produzido. Na religião egípcia, portanto, isto pode ser observado na conservação das múmias abrigadas no interior das pirâmides como o Si morto, ou como uma projeção causada por um raio de luz. ${ }^{17}$

Por conseguinte, o esforço do trabalho do artesão é encontrar uma maneira específica para imprimir unidade entre a obra que é burilada e a consciência-de-si que a produz. Como afirma Hegel, "seu esforço ulterior deve tender a suprassumir essa separação da alma e do corpo, a revestir e a modelar a alma nela mesma, e, por sua vez, a infundir alma no corpo". ${ }^{18}$ Deste modo, ao conferir alma à sua obra, o Espírito alcança o feito notável de reconhecer-se no objeto tal como ele é. Mas isto ocorre somente quando a convergência for perfeita, o que ainda não é o caso nesse momento da religião natural. ${ }^{19}$

Para Hegel, nessa forma de religião o artesão já constrói suas obras mesclando o pensamento com as fragilidades da natureza, figuras anteriores deste processo. Aqui, o Espírito transforma aquilo que é mais natural e o aproxima das formas universais presentes em si, por exemplo, o início da elevação de colunas robustas carregadas de noções formais de retas e curvas. Ademais, neste estágio, a obra se transforma assemelhando-se ainda mais à consciência-de-si que a realizou. No início, ao invés, eram utilizadas formas animais, como símbolos, para indicarem uma ideia ou um pensamento; em seguida, porém, o artesão mistura a figura do animal com a do homem, humanizando assim, paulatinamente, aquilo que lhe fora dado. ${ }^{20}$

Além disso, o que falta à religião do artesão é a expressão da essência absoluta pela linguagem, que é onde o Si habita por excelência. Hegel apresenta nesta fase da religião alguns indícios ou aparências de linguagem como, por exemplo, a estátua de Ménon ao emitir uma espécie de som quando a luz do sol, pela manhã, incidia sobre a sua superfície. Entretanto, ressonância não significa propriamente linguagem, pois se trata de algo que é causado pelo exterior e não provém de um Si interior, ou seja, de um sujeito que pensa, fala e, portanto, deseja. Outro exemplo de aproximação de linguagem nesta religião é a Kaaba de Meca, mas aqui também se trata muito mais de um habitáculo inessencial que

\footnotetext{
${ }^{17}$ Cf. MENESES, op. cit., 1985, p. 176.

${ }^{18}$ Cf. HEGEL, op. cit., v. 2., 1993, p. 155.

${ }^{19}$ Cf. ibid., p. 177.

${ }^{20}$ Cf. MENESES, op. cit., 1985, p. 177.
} 
não possui toda aquela variedade de figuras vivas; ele indica antes um interior escuro, simples, tenebroso e misterioso. ${ }^{21}$

Ora, o artesão, mesmo sem saber o que faz nessas duas representações, ele traduz gradualmente em suas obras os dois momentos do Espírito: o interior e o exterior. O que acontece posteriormente neste processo é o caminho que unificará estas duas representações, porquanto a estátua, mesmo em forma humana, não expressa o interior. Ela não possui a linguagem, de sorte que o interior nada tem a ver com as suas reverberações exteriores, como a ressonância provocada pela luz do sol. Quando, porém, o artesão acopla numa só figura a imagem do animal e a imagem do homem, ele já está perfazendo a tarefa de aproximar e identificar esses dois momentos do Espírito. Contudo, o que ainda permanece é uma luta constante de clareza de expressão com a opacidade do pensamento, que não se expressou em linguagem. ${ }^{22}$

Isto, no entanto, permite ao artesão passar para um outro patamar, na medida em que ele encerra a produção pelo instinto e pelo inconsciente. Agora o Espírito, na unidade de seus momentos, não é meramente figura da consciência, mas também objeto dela, e as espécies de hibridismo religioso vão se purificando cada vez mais ou, para dizê-lo com outras palavras, as produções do Espírito dentro da religião passam a exprimir um caráter espiritual. Neste último momento da religião natural, pondera Hegel: “esses monstros se dissolvem em uma figuração espiritual: em um exterior que se recolhe em si; em um interior que se exterioriza a partir de si e em si mesmo". ${ }^{23}$ Deste modo, o artesão se transporta para aquilo que ele produz, na medida em que ele faz do seu Si o próprio objeto de sua experiência, de sua intenção e de sua trama. Em outros termos, ele deixa de ser meramente artesão e se torna artista, isto é, criador ou, mais exatamente, re-criador de si próprio. A religião natural se transforma assim em religião da arte.

\section{A religião da arte}

A religião da arte aparece, pois, quando o artesão, que antes combinava as características do pensamento e do dado bruto da natureza, dos homens e dos animais, começa a afastar-se do simples trabalho instintivo e sintético e empreende uma atividade consciente-de-si. Destarte, ele deposita em suas obras a sua essência e se torna um

\footnotetext{
${ }^{21}$ Cf. MENESES, op. cit., 1985, p. 177.

${ }^{22} \mathrm{Cf}$. ibid.

${ }^{23}$ Cf. HEGEL, op. cit., v. 2., 1993, p. 157.
} 
trabalhador de ordem espiritual, ou intelectual. Portanto, neste momento da figura da religião a essência divina deixa de ser representada por formas naturais ou combinações da natureza com o pensamento e começa a ser representada pelas formas do Si individual, a partir daquilo que é essencial e universal no Espírito do artista. Esta religião da arte está em íntima relação com o espírito ético, que é a substância mais efetiva e universal dentro do espírito objetivo. Aqui, os sujeitos estão ligados entre si, podendo assim admitir sua essencialidade num processo construído por todos. ${ }^{24}$ De resto, neste estágio, foi superada a figura da essência da luz, cuja consciência para-si era desprezada e considerada inessencial; foi também suprassumido o combate violento dos povos sanguinários e o sistema de castas sociais em que se demonstrava uma carência de liberdade. À diferença, pois, de uma religião centrada nos animais, entramos agora num outro momento, isto é, numa religião de um povo livre, que possui consciência de sua liberdade e que reconhece em seus mores (costumes) a vontade própria e o livre agir de cada um de seus membros.

Para Hegel, o ambiente mais propício para a construção dessa forma de religião foi o do povo grego, que se reconhecia como um povo livre e artífice de suas cidades-estados autônomas e pautadas por uma eticidade. Na pólis, os indivíduos encontravam sua liberdade, diferentemente das outras civilizações divididas em castas e pautadas pela hostilidade e pela opressão. Consequentemente, ao se perceber livre, o sujeito constrói a imagem de seus deuses de acordo com a sua própria imagem de homem livre. Isto se torna tão evidente que a religião da arte encontrará sua realização mais autêntica no teatro grego, em que o espírito universal individualizado é representado pela figura do herói, que tenta ser o dono de seu próprio destino e de sua própria paixão, apesar da mão de ferro implacável das Moiras.

Todavia, mesmo se admitindo que a religião da arte na expressão grega manifesta o Si individual e a figura humana em suas divindades, ela ainda não é a mais espiritual das religiões. De certa forma, nela o Espírito se apresenta de modo muito imediato, justamente pelo fato de seus deuses, mesmo sendo espíritos livres, mostrarem-se incapazes de suprassumir em si mesmos a essência universal. Sabe-se, com efeito, que cada deus grego tem uma particularidade e uma personalidade característica. A religião da arte se mostra, portanto, contingente, pois ela expressa tão somente a essência universal subsumida pela individualidade do $\mathrm{Si}$, e não a individualidade do Si subsumida

\footnotetext{
${ }^{24}$ Cf. MENESES, op. cit., 1985, p. 178.
} 
pela essência universal, como acontece na religião revelada e, mais precisamente, no cristianismo. ${ }^{25}$

Convém, porém, enfatizar que a religião da arte também apresenta o seu desenvolvimento dialético e evolui sempre mais para a combinação do espírito humano com a sua produção da essência divina, pela qual ela tenta reconhecer-se. Nela, Deus vai se tornando homem e passa a receber muitas características antropomórficas. Então, num primeiro momento, a religião da arte apresenta a essência absoluta através do $\mathrm{Si}$ individual, na figura imóvel da estátua; posteriormente, ela se mostra também nos hinos e nos cultos, até encontrar-se na obra-de-arte-viva e nos cultos de mistério prestados ao deus do vinho e à deusa das colheitas e da fertilidade. Ademais, a religião da arte se expressa na exaltação do corpo dos atletas olímpicos, considerados como deuses-homens, e, por fim, ela atinge o seu ápice na construção da linguagem mais desenvolvida e presente no teatro grego: na epopeia, na tragédia e na comédia. Assim, destaca-se a primeira obra de arte realizada neste momento da religião: a obra de arte abstrata. Essa obra, como primeiro momento, é o estágio da religião da arte mais imediata e mais abstrata, justamente porque ainda não se colocou completamente a caminho da consciência-de-si; ela ainda não a reflete nem produz um tipo de arte que tenha vida em si mesma. ${ }^{26}$

Na perspectiva de Hegel, a primeira figura dessa obra de arte abstrata é a obra plástica, na qual podemos incluir as imagens dos deuses, as esculturas e até mesmo a arquitetura, que em relação à consciência ativa é uma "coisa". Na arquitetura, os templos e edifícios possuem caráter de universalidade e nas esculturas o de singularidade. Neste sentido, o artista, diferentemente do homem da religião natural, já começa a introduzir em sua obra indícios de sua consciência, atribuindo-lhe assim várias significações. Como observa Hyppolite, tanto na arquitetura como na escultura, o Espírito se representa a si mesmo como um reflexo daquilo que brota do espírito humano. ${ }^{27}$ Então aquele que esculpe coloca no templo imagens de deuses com total aparência e alguns atributos humanos para serem cultuados. Pode-se, pois, deduzir que esse estágio primordial da religião da arte suprassumiu a religião que lhe era anterior, porquanto as essências divinas naturais foram sendo superadas. Pense-se, por exemplo, no "mundo dos Titãs" como um resultado da fusão da Luz com as Trevas, ou do Céu com o Mar, etc. As imagens divinas, agora, representam os espíritos da realidade ética das suas respectivas civilizações, que são

\footnotetext{
${ }^{25}$ Cf. CALDAT, op. cit., 2013, p. 90.

${ }^{26}$ Cf. MENESES, op. cit., 1985, p. 179.

${ }^{27}$ Cf. HYPPOLITE, op. cit., 1974, p. 497.
} 
conscientes de si mesmo e de sua liberdade. Nas figuras serenas de seus deuses, pode-se mesmo encontrar o constante combate presente na consciência-de-si, ou seja, a inquietude diante de sua infinitude e de seu caráter mutável. ${ }^{28}$ Todavia, mesmo diante desses fatores, o artista não é consciente de que o que ele produziu não é algo a ele exterior, mas é fruto de suas próprias mãos. Tanto o artista, como o povo, que admira e adora as estátuas divinas, não reconhecem que elas são produções de sua própria essência. $\mathrm{O}$ artista produz a figura da divindade, mas ainda não produziu a unidade entre o seu fazer e a coisa mesma representada. Deste modo, essa obra de arte ainda não é viva nem consciente de si.

Convém, no entanto, notar que, como outra produção da obra de arte abstrata, se acha também a composição e a reprodução dos hinos dentro da religião da arte. A divindade não pode ser depositada na escuridão e na inconsciência das estátuas, de sorte que é necessário ir além nesse processo de manifestação da essência espiritual. Encontra-se, portanto, no processo dialético, a linguagem como expressão superior. Trata-se de uma realidade mais consciente-de-si, que contagia a todos e atinge a variedade dos indivíduos em sua singularidade. Agora, a religião também transmite os hinos, em que a linguagem constitui a representação da essência absoluta. Com efeito, o hino é a alma que faltava na coisificação das imagens divinas; ele é singular por ser a expressão da consciência-de-si que pensa e possui um fervor devoto, mas ele é também universal, porquanto, ao ser escutado, constitui uma linha de adesão de mais devotos fervorosos. ${ }^{29}$

Juntamente com o hino na religião da arte - enfatiza Hegel - tem-se também a presença do oráculo, uma outra espécie de linguagem que se acrescenta à obra de arte abstrata. Nesta, decerto, não encontramos a característica do envolvimento universal que os hinos acarretam nas comunidades que os compõem e os reproduzem. O oráculo provém antes de um sujeito singular separado dos demais; por este motivo, ele é também contingente, pois aparece como uma voz diferente da voz universal e necessária, presente na comunidade. A voz do oráculo, portanto, é de uma origem estranha e esse tipo de guia espiritual possui apenas uma função e uma utilidade, qual seja, a de conduzir específicos sujeitos na contingência do acaso de suas vidas.

Por fim, como processo dialético da obra de arte abstrata, deve-se ressaltar a representação do culto, que surge no próprio desdobramento da religião da arte. $\mathrm{Na}$ verdade, nesta perspectiva abstrata, tudo até agora levou ao surgimento do culto, que suprassume as diferenças e sustenta uma unidade dentro da religião. O culto se apresenta

${ }^{28}$ Cf. MENESES, op. cit., 1985, p. 179.

${ }^{29}$ Cf. ibid., p. 180. 
deste modo como o caminho ou como o ponto de união entre a essência divina - que plaina, por assim, numa espécie de além - e a consciência humana. É o próprio Hegel quem o diz: "No culto, o Si se proporciona a consciência da descida da essência divina desde o seu além até ele; desse modo, a essência divina, que anteriormente é o inefetivo e somente objetivo, adquire a efetividade própria da consciência-de-si". ${ }^{30}$ No culto temos, portanto, a convergência da exterioridade inefetiva das estátuas divinas e a interioridade presente na linguagem dos hinos.

Segundo Hyppolite, o desenvolvimento do culto, dentro da religião da arte, indica o início de uma viva unidade entre o divino e o humano, entre a essência absoluta e a autoconsciência, justamente porque no culto encontramos os deuses olímpicos que circundam os humanos, manifestando-se com o seu poder e exuberância além deles, mas que, ao mesmo tempo, só existem a partir do reconhecimento do próprio homem. Podese, pois, afirmar que dos indivíduos é que o deus abstrato tem consciência de si mesmo, pois são os indivíduos que o nomeiam. O que temos aqui é sempre uma "via de mão dupla", no sentido em que o divino só se torna divino com a ajuda do homem e o homem somente se encontra a si mesmo buscando o divino. Há uma espécie de purificação e de renúncia de ambos os lados, como podemos observar na constituição do sacrifício, dentro do culto: nele o homem sacrifica a sua particularidade entregando-a como frutos ou animais oferecidos. Estes são ao mesmo tempo os símbolos dos deuses que se dão e se sacrificam, de um certo modo, ao próprio homem. No culto, portanto, os deuses renunciam à sua universalidade e se entregam ao homem. Mas no animal ou no fruto sacrificado é o homem que sacrifica a sua particularidade ao entregar-se a essa universalidade, e ele o faz através da beleza e do desempenho nas liturgias e cerimônias religiosas. ${ }^{31}$

Depois desse momento, a obra de arte deixa de ser puramente abstrata e se torna uma obra de arte viva. Esse estágio da religião se realiza justamente por causa da unidade entre o divino e o humano, pois é o homem mesmo que toma consciência de si e, simultaneamente, passa a ter consciência de que é um com a essência divina. A isto, Hegel chama de mistério, não um mistério que se dá como velamento ou como um simples nãosaber, mas como um conhecimento de um Si que se reconhece unido com a sua essência. Deste modo, a essência da própria natureza se dá ao homem e penetra a sua vida revelando a sua profundidade. Nesse sentido, a essência, a partir do culto, que se transforma em

${ }^{30}$ Cf. HEGEL, op. cit., v. 2., 1993, p. 164.

${ }^{31}$ Cf. HYPPOLITE, op. cit., 1974, p. 498-499. 
comida e bebida, agora se apresenta como um objeto a ser desejado e a ser usufruído, no exemplo dado pelo filósofo dos ritos de Ceres e Baco - pão e vinho - que antecedem o sacrifício do Espírito consciente-de-si do Corpo e do Sangue, da religião revelada. ${ }^{32}$

Agora, todo esse fruir de unidade com o divino se traduz, não mais e somente na quietude das estátuas divinas, mas também nas festas religiosas em honra do homem como um ser que se une a um deus. Essas festas são repletas de vida e de movimento, em que o ser humano toma para si o protagonismo das estátuas. O homem, a partir desse momento, vai se tornando uma representação externa e corporal da essência divina, anteriormente só relacionada com a luz, com os animais, com as estátuas, com os templos, com os hinos, os oráculos e os cultos. Ademais, para suprassumir essas formas de expressão, suprassumiu-se também a linguagem presente na contingência dos oráculos e no devotamento a um deus particular nos hinos. Esta linguagem se torna agora mais clara e universal. ${ }^{33}$

De resto, temos na religião da arte um terceiro momento no processo de determinação da figura religiosa, trata-se da obra de arte espiritual. Neste tipo de religião encontramos os espíritos dos povos reunidos e unificados num mesmo espírito, num Panteão constituído especificamente pela linguagem, a partir da epopeia. Neste estágio de determinação da religião da arte verificamos, portanto, a obra de arte espiritual. ${ }^{34}$ Neste sentido igualmente - por meio dos poemas heroicos - a divindade passa a ser representada pela figura de homens valentes que realizaram, histórica ou hipoteticamente, grandes vitórias e carregaram, com o seu caráter, histórias decisivas para a vida de seu povo. Assim, na sua linguagem, a religião da arte foi elevada à linguagem mais universal, o que possibilitou a reunião dos deuses e unificou até mesmo a concepção do povo grego em sua totalidade. Na perspectiva de Hegel, essa linguagem possuía o conteúdo universal apenas como totalidade do mundo, mas não ainda como realidade universal do pensamento. ${ }^{35}$ Pois o seu mantenedor era o aedo, que não participava das histórias por ele contadas, mas as relatava, criando o mundo e penetrando, através da linguagem, a essência absoluta. ${ }^{36}$

Segundo Hegel, o aedo possuía um diferencial que deslocava o conteúdo religioso para mais próximo ainda do Espírito: a Mnemosyne. Assim, ao invés de ser guiado pelo pathos

\footnotetext{
${ }^{32}$ Cf. MENESES, op. cit., 1985, p. 182.

${ }^{33}$ Cf. ibid., p. 182-183.

${ }^{34}$ Cf. HEGEL, op. cit., v. 2., 1993, p. 171.

${ }^{35}$ Cf. HEGEL, op. cit., v. 2., 1993, p. 172.

${ }^{36}$ Cf. CALDAT, op. cit., 2013, p. 96.
} 
em forma de natureza, ele era conduzido pela própria memória, um conteúdo mais espiritual, a partir da qual era capaz de rememorar e trazer constantemente presente a essência divina que antes era imediata. Deste modo, ele não cantava o seu Si mesmo, mas a sua Musa, isto é, a sua música universal que o mostrava apenas como um instrumento desses cantos universais. Tratava-se de um ser singular que relatava a universalidadeparticular dos heróis - figuras médias que se situam entre os deuses e os homens - e a universalidade-plena dos deuses. ${ }^{37}$

Agora, na epopeia, há uma aproximação bem maior entre o divino e o humano, já presente outrora nos cultos, justamente por unificar melhor a essência absoluta e a consciência-de-si do sujeito. Entretanto, existem também muitas confusões nessa tentativa de unidade entre deuses e homens. Nas epopeias, os deuses tomavam o lugar dos homens ou assumiam o seu papel e a sua condição de serem livres e agentes no mundo. Ao mesmo tempo, porém, o homem assumia o papel da eternidade e da imortalidade dos próprios deuses. Há, portanto, um constante paradoxo, no qual os deuses se encontravam como sujeitos individuais fragilizados pela efemeridade do mundo, mas, ao mesmo tempo, se apresentavam como o elemento universal que sustenta os homens. ${ }^{38}$

Além dessa constante oposição entre os deuses e os homens na epopeia, há também uma contínua oposição entre os próprios deuses, que estão sempre em algum embate e que, por estarem determinados em suas características, deixam de lado a sua essencialidade divina. É uma espécie de "fanfarronice" essa a dos deuses, justamente porque se mostram aos homens como seres universais invencíveis, mas entre si ainda vivem sob o domínio da Necessidade.

Com efeito, todo esse descrédito ou confusão causada na consciência-de-si de cada sujeito em relação à essência absoluta e universal dos deuses, representada nas epopeias, passa a crescer no progresso da religião da arte, de sorte que e a figura dos heróis começa a desmoronar, pois os deuses são desfocados e o aedo singular não é mais um instrumento tão importante como o era antes. É que agora, na religião da arte se abre o espaço para uma outra figura da obra de arte espiritual, que supera a primeira e avança através desse plano: a tragédia. Na linguagem trágica foi suprassumida a narrativa dos poemas heroicos e épicos; o número dos personagens foi reduzido ao essencial e o conteúdo não fíca lançado à deriva, mas conduzido por um fio racional. O próprio herói agora fala e não mais se fala dele; os espectadores são homens livres e autoconscientes, pois eles

${ }^{37}$ Cf. CALDAT, op. cit., 2013, p. 96.

${ }^{38}$ Cf. ibid., p. 97. 
conhecem os seus desejos, direitos e deveres. Certo, na tragédia existem também homens que personificam os heróis de outrora e os explicitam em sua própria linguagem, pois estão preocupados em expor mais as individualidades universais dos personagens e não tanto as circunstâncias contingentes de cada um em particular. ${ }^{39}$

A tragédia, portanto, unifica ainda com mais efetividade a essência absoluta com a vida do homem, que agora encara a figura do herói com total entrega e radicalidade nas encenações apresentadas a um coro composto por espectadores. Nesse sentido, ao contrário do aedo na epopeia, a tragédia traz a presença do ator, que não somente narra os poemas heroicos, mas também interpreta ele mesmo a vida do herói ou dos deuses a serem representados e expressados. Ainda na tragédia, cada ator coloca diante do rosto uma máscara que representa um herói ligado espiritualmente a alguma figura divina. Destarte, encontramos o Si consciente da essência absoluta na imagem do ator, embora ele ainda se encontre camuflado por detrás do personagem que ele mesmo interpreta, ou representa. Certo, o ator encarna um herói. Mas antes de considerar as características do herói trágico, devemos observar que a tragédia é composta por alguns elementos cruciais na sua composição e na condução de seu progresso rumo à comédia: o coro, os heróis, a lei divina, a lei humana e os deuses.

Dentro da tragédia, o coro representa o povo que, segundo Hegel, está num segundo plano nesse estágio. No entanto, ele tem uma função no desenrolar trágico da obra de arte: uma participação passiva. Mesmo representando os setores sociais, a cultura e a tradição de seu povo, o coro não possui o ímpeto necessário para confrontar a lei divina ou a lei humana, que estão em constante dissonância entre si. Isto significa que o coro não possui toda a riqueza do povo, mas tampouco assumiu em si a vida dos deuses. Neste sentido, ele se apavora e estremece, como espectador, com as encenações dos atores nas tragédias que enfrentam essa realidade dual entre a lei humana e a lei divina. Ao mesmo tempo, apresentam-lhe o fato de que tudo desemboca na necessidade e no destino.

Toda tragédia tem como principal conteúdo uma ou mais aporias, das quais o herói, interpretado pelos atores, deve tentar encontrar uma saída, mesmo se ela se lhe afigure como uma impossibilidade ou "um caminho sem volta". Dentro da tragédia, portanto, o herói sempre representa essa dualidade encarnada entre a vontade dos deuses e a vontade dos homens, de sorte que existe uma constante dualidade entre o direito humano e o direito divino. Ao assumir qualquer um desses caráteres em sua determinação,

\footnotetext{
${ }^{39}$ Cf. MENESES, op. cit., 1985, p. 184-185.
} 
automaticamente instigará a potência vingativa do outro caráter. Cada personagem encarna ou a vontade divina ou a vontade humana, não é possível a concretização das duas ao mesmo tempo numa tragédia. Em outros termos, ou o herói satisfaz seu desejo e transgrede a lei divina, ou cumpre a lei divina, não satisfaz seu desejo. Assim, ao assumir um desses caráteres, o herói fere inexoravelmente o outro: se ele encarnar a lei humana, ferirá implacavelmente a lei divina, mas se encarnar a lei divina, ferirá inelutavelmente a lei humana.

Portanto, cada tragédia tem sempre a presença de duas classes de heróis que se embatem, ou se contrapõem. É, enfim, um mundo que está cindido no conceito que se divide internamente entre o saber e o não-saber, ao que Hegel representa, respectivamente, pelo deus Apolo - deus da luz e do saber, entre outros atributos - e pelas deusas Erínias: deusas da escuridão e da vingança. A tentativa, nesse progresso da tragédia, é a busca por uma unidade e por uma reconciliação entre essas duas forças, que é a unidade da própria substância ética de todo povo. É necessária, portanto, uma terceira força divina que suprassuma essas duas potências antagônicas, e essa força é a figura de Zeus, o deus dos deuses, que reúne em si mesmo as duas posições e constantemente as relaciona entre si. Zeus, desse modo, representa o campo da necessidade e do destino presente na tragédia, ele acaba com as oposições das situações conflitantes da tragédia e da luta entre os deuses, pois tudo converge para ele, no inevitável e certo poder do destino que, segundo Hyppolite, é a própria autoconsciência, a simples certeza de si mesmo, o sinal dessa unidade, dessa essência substancial e dessa necessidade abstrata. ${ }^{40}$ Zeus é representação da autoconsciência.

Efetivamente, ao tomar consciência de si como unidade entre essas forças avassaladoras, presentes na tragédia, o ator trágico pode retirar as suas máscaras e perceber-se como um "si" individual, que se reconhece um joguete nas mãos de tais potências divinas e universas. Esta é razão pela qual sua linguagem trágica e conflituosa, graças à angústia constantemente presente diante das forças divinas que conduzem o seu destino, é transformada numa linguagem cômica, com a qual o ator se trata com ironia. ${ }^{41}$ $\mathrm{O}$ ator deve necessariamente criar o cômico em seus enredos e na obra de arte espiritual da religião. Na verdade, ele deixou sua máscara porque ela o confundia e o elevava acima de si próprio. Ao deixá-la, portanto, ele assume seus elementos substanciais como simples momentos finitos que só possuem significado em si mesmo.

\footnotetext{
${ }^{40}$ Cf. HYPPOLITE, op. cit., 1974, p. 502.

${ }^{41}$ Cf. CALDAT, op. cit., 2013, p. 100.
} 
Na comédia, portanto, os heróis deixam de ser heróis e se mostram como homens comuns. $\mathrm{O}$ ator sem a máscara, agora, demonstra a sua nudez e revela ser a mesma coisa que o Si verdadeiro e ordinário. Agora, as realidades humanas que estavam divididas tanto na epopeia como na tragédia se unificam no homem sem máscaras, sujeito às instabilidades e contingências da vida, a vida que ironiza a aspiração a ser aquelas potências éticas universais. ${ }^{42}$ A linguagem cômica representa justamente a realidade de um personagem que, ao se lançar para de si na universalidade da essência absoluta, acaba por encontrar a si mesmo como indivíduo, ou como o resultado das lutas dos deuses e do destino que, outrora, se desenrolavam na tragédia. Agora, restam-lhe a ironia e o riso. A comédia, em suma, é a consciência que o si individual passa a ter ao se deparar com as realidades banais e contingentes do cotidiano. $\mathrm{O}$ si individual desprende-se agora das essências natural e ética e se vê solitário e disperso do todo. Por conseguinte, a ironia cômica não escancara somente as fragilidades dos homens, mas explicita igualmente as debilidades e inconstâncias dos deuses. ${ }^{43}$ Mas a comédia é também o resultado de um mundo grego que foi se transformando e assumindo como forma de governo a democracia. Consequentemente, ela é um produto cultural de um povo que olha para si e pensa depender somente de si, que julga não depender da vontade de senhores e de reis, e nem mesmo do capricho das potências divinas.

Então, quando assoma esse si individual na comédia, pode-se detectar a decadência e o fim do momento da religião da arte grega. Paradoxalmente, porém, neste percurso dialético da religião, surge, dentro desta mesma marcha do Espírito Absoluto, um outro momento, ou uma nova figura da religião: a religião revelada.

\section{A religião revelada}

A religião revelada é, pois, o terceiro momento da religião na marcha do Espírito Absoluto. Ela é - ainda no pano de fundo da representação - aquela figura religiosa que mais se aproxima do Saber Absoluto e, portanto, do pensamento que se pensa plenamente como pensamento ou, em outros termos, como puro conceito. Como vimos na primeira seção deste estudo, na religião natural o homem tinha a divindade ou a essência absoluta como um ser abstrato, animado e externo a ele próprio. Na segunda seção - relativa à

\footnotetext{
${ }^{42}$ Cf. HYPPOLITE, op. cit., 1974, p. 503.

${ }^{43}$ Cf. CALDAT, op. cit., 2013, p. 100.
} 
religião da arte - deparamos com a essência absoluta humanizada e espiritualizada no si individual daqueles que encarnavam tal realidade nas estátuas, na linguagem, na epopeia, na tragédia e, enfim, Agora, porém, na religião revelada há a retomada da essencialidade universal, destruída no espírito humano pelo surgimento do pensamento racional independente das culturas grega e romana antigas; isto se dá graças ao estoicismo e ao ceticismo. O desafio consiste, pois, em fazer com que o si individual volte a encontrar dentro de si mesmo a essencialidade universal perdida, mas constantemente almejada por ser essencial ao caráter universal do espírito humano. Deste modo, neste novo momento da religião, temos o si individual que renuncia a si mesmo ou se suprassume para encontrar a essência absoluta que já está dentro dele mesmo.

Consequentemente, a religião revelada já pressupõe a descida da essência absoluta ao si individual, que a religião da arte já realizou em seu desdobramento. Como pudemos contatar, na religião da arte o si individual era sinal e presença da essência absoluta, todavia, aconteceu que o sujeito passou a sentir-se superior e dominador desta mesma essência através da razão e do pensamento. Isso ganhou mais força no espírito jurídico da antiga Roma, em que o si adentrou cada vez mais o interior de seu pensamento e, ao mesmo tempo, explicitou e reconheceu a sua independência. Isto se deu mais especificamente nos momentos históricos do estoicismo e do ceticismo, enfatizados por Hegel no processo de dependência e independência da consciência-de-si e para-si. Tratase do famoso capítulo IV da Fenomenologia do Espírito, significativamente intitulado: A verdade da certeza de si mesmo. Aqui se deduz que existe um si cindido em duas situações: de um lado, ele é finito, por estar jogado no mundo, e, de outro, ele é infinito, justamente por ser capaz de pensar infinitamente. Hegel designou esta dinâmica de cisão pela expressão: consciência infeliz. A consciência infeliz sente a dor da perda e da falta da essencialidade universal, que outrora fora ironizada pela consciência cômica. Na frase, "Deus morreu", a consciência se vê vazia, sem sentido, e o si não sabe mais o que lhe é essencial. $^{44}$

Na história da humanidade, portanto, a consciência-de-si cindida e infeliz em sua nãoessencialidade, associada também às religiões da arte, ao estoicismo e ao ceticismo, precisa retornar à sua essencialidade e buscar a unidade com ela. Neste contexto, em que a religião revelada se desdobra com o intuito de suprassumir a negatividade, ela sobreleva o si da consciência infeliz e, ao mesmo tempo, tenta transformá-lo no si universal. Daí

\footnotetext{
${ }^{44}$ Cf. HEGEL, op. cit., v. 2., 1993, p. 184.
} 
não ser difícil deduzir que o conteúdo da religião revelada está no Cristianismo, que se traduz pela encarnação da essência divina, cujo si universal se torna si individual para que este se reconcilie consigo mesmo e se torne também si universal. Nesta figura da religião, a essência universal passa, de fato, a ter consciência-de-si e consciência de que é Espírito. Trata-se de um si individual e determinado, literalmente encarnado num homem singular, que se esvaziou, sofreu a morte de cruz, foi elevado aos céus e adorado por um fervor devoto. Destarte, verificamos na religião revelada o caminho desejado pela consciência infeliz, que é o de reunir a sua finitude à sua infinitude, o si abstrato da consciência à realidade do mundo múltiplo e fragmentário.

Esta figura do deus encarnado, na religião revelada, já exprime e demonstra a verdade do Espírito, cuja consciência-de-si possui consigo a essência universal e revela o divino. Nela, a unidade entre as realidades humana e divina é finalmente intuída, justamente quando nela se encerra a representação da renúncia de ambas as partes: primeiramente, a essência renuncia a si mesmo em favor do si individual - é o momento da encarnação da divindade -, há depois a renúncia do si individual para que se releve a essência universal, ou seja, o momento da fé e da rememoração da comunidade religiosa. Deste modo, a religião revelada primeiramente explicita uma essência universal divina que se torna um si individual existente num homem, e é este mistério da encarnação que acarreta a crença de outros "sis" individuais que passam a acreditar e tomar consciência de que o seu próprio si singular pode, ele também, fazer parte da tão desejada essencialidade universal. Efetivamente, a religião revelada é o estágio da religião que, literalmente, dá carne e atualidade individual ao universal.

Ajunte-se a isto que a religião revelada não para no fato da encarnação, em que a essência possui uma consciência imediata de si. Convém também que a essência seja uma consciência religiosa. Mas para que ela seja uma religião revelada, a presença deste universal encarnado necessita igualmente de ser apreendida como pensamento, já que Deus se revela tal como é: espírito e puro conceito. ${ }^{45}$ Portanto, enquanto si individual, encarnado, a essência não é ainda para o outro, e por isso não retorna ao que é: essência universal. Como homem divino ele somente é apreendido pelos indivíduos no campo da sensibilidade, ao ser ouvido, tocado, visto, etc. Porém, ao se tornar pensamento, ele é também apreendido por todos através do entendimento. Paradoxalmente, o nível da percepção se perde com a morte desse si singular divinizado, mas, ao se tornar

\footnotetext{
${ }^{45}$ Cf. MENESES, op. cit., 1985, p. 191.
} 
pensamento, ele pode ser recuperado na memória daqueles que creem em sua essência universal. ${ }^{46}$ É nesta rememoração do homem divino que a verdade ou essência deste si individual pode ser assumida por uma comunidade inteira de "sis" individuais que se veem na figura do deus encarnado. Esta memória ainda é uma forma pela qual aquela verdade da unidade entre o divino e o humano se torna espiritual, na medida em que uma consciência individual se torna uma comunidade religiosa. Para Alexandre Kojève, a vida de Cristo e sua morte simbolizam o curso real da história, porquanto Cristo sacrifica sua Particularidade (Jesus) para realizar o Universal (Logos) e o Universal (Deus) reconhece esta Particularidade (Homem), que é o próprio Deus (Cristo). ${ }^{47}$ Portanto, já não é mais o si individual singular - Cristo -, mas ele conjuntamente com a consciência da história e da comunidade como elemento que formam a totalidade do Espírito. Trata-se, pois, de uma essência que desce até o si individual, e de um si individual que retorna à essência universal.

Entretanto, mesmo considerando a comunidade religiosa como aquela que se encontra numa ligação íntima com a essência divina, podemos ainda ressaltar que esta consciência religiosa ainda caminha no nível da representação. De resto, esta é a característica do estágio da religião no desdobramento do Espírito Absoluto, a de continuar sendo, conforme assevera Hegel, “a união sintética da imediatez sensível e de sua universalidade, ou do pensar". ${ }^{48}$ Assim, mesmo com a elevação espiritual do si individual, ainda é notória uma divisão entre a consciência e a essência, o pensar e o ser, o finito e o infinito, o particular e o universal. Todavia, convém notar que é dessa forma que o Espírito se torna consciente de si mesmo, mesmo ainda não tendo adentrado a esfera do puro conceito. Nesse sentido, a religião revelada, por mais absoluta que seja, carece ainda de algo, algo que exige o puro conceito do Saber Absoluto, justamente porque a memória que conduz a comunidade religiosa permanece, por assim dizer, estagnada. Seu conteúdo é ou a revelação de um homem que se uniu à essência universal e que permanece no passado, ou algo do qual se espera um retorno no futuro. ${ }^{49}$

Por fim, é importante sublinhar que a religião revelada também possui um movimento dialético próprio, cujo conteúdo espiritual - dessa reconciliação entre o si individual e a essência universal - revela-se à comunidade religiosa em três momentos: primeiro, como

\footnotetext{
${ }^{46}$ Cf. CALDAT, op. cit., 2013, p. 106.

${ }^{47}$ Cf. KOJÈVE, op. cit., 1947, p. 262.

${ }^{48}$ Cf. HEGEL, op. cit., v. 2., 1993, p. 192.

${ }^{49}$ Cf. ibid.
} 
pura substância ou pensamento puro (o Pai); segundo, como consciência-de-si singular (o Filho, o si individual); terceiro, como consciência-de-si universal da comunidade religiosa (o pensamento universal - Espírito Santo). Outrora, na consciência infeliz, essa realidade espiritual era vista como algo inalcançável, como um conteúdo completamente objetivo da representação, mas distinto da certeza da consciência-de-si. Agora, na religião revelada, a comunidade religiosa assume esse conteúdo para si como sua substância, na medida em que, segundo Hegel, também encontra nela a certeza do seu próprio Espírito. ${ }^{50}$

Essa dinâmica triádica da religião revelada é a figura ou a imagem do próprio Absoluto que se desdobra na natureza e na história e a si mesmo retorna pelo Espírito. São os momentos claros, portanto, da própria dialética apontada por Hegel na formação de seu sistema. No estágio da religião, especificamente, estão presentes: o momento da essência pura, o momento do ser-para-si no Outro (no caso, o Verbo, como movimento de ouvirse a si mesmo), e o momento que sabe a si mesmo no outro, à medida que passa a ser reconhecido. Mas isto só se torna possível na medida em que ele for reconhecido por outra consciência, isto é, seu Outro, seu negativo. Com efeito, esse último momento que reconhece a essência abstrata é a comunidade religiosa, que ainda não entende a necessidade dialética da realidade daqueles dois primeiros momentos e por isso representa-os por meio das figuras naturais do Pai e do Filho, dividindo um momento do outro e se retirando a si mesma dessa relação. Na verdade, os três momentos se realizam simultaneamente, pois um desemboca necessariamente no outro. Todavia, o conteúdo da comunidade cristã separa esses momentos da seguinte maneira: o Pai é a pura essência pensada, a substância que se transforma e cria um mundo na consciência do si singular do Filho, que, ao ser aceito como verdade, demonstrar-se-á à Igreja que sabe estar em unidade com o Pai através e a partir do Filho. ${ }^{51}$

De resto, é no seio da comunidade religiosa que é possível a reconciliação entre o Bem e o Mal presente no interior de cada si particular: o Bem é a consciência e a união com a essência universal, logo, o Mal é o afastamento da essência universal e o assumir da natureza como a essência do homem. Assim, o homem permanece numa constante dualidade ou numa contínua tensão interior que só pode ser definitivamente resolvida no si singular divino, que assume totalmente em si a essência universal, isto é, Cristo. Este, por sua memória na comunidade cristã, permite que os indivíduos, que a ela aderem,

\footnotetext{
${ }^{50}$ Cf. HEGEL, op. cit., v. 2., 1993, p. 193.

${ }^{51}$ Cf. CALDAT, op. cit., 2013, p. 108.
} 
tomem consciência do bem e busquem agir de acordo com ele. Assim formarão um só ser com a essência universal. ${ }^{52}$

Para isto, o si individual, unido à essência universal que põe fim à luta entre as potências do bem e do mal, só levará a cabo essa reconciliação quando finalmente desvanecer a sua presença sensível e ele puder retornar, como essência universal refletida em si mesma, à consciência universal da comunidade religiosa. Por isso, o elemento comunitário é de suma importância no desdobramento da religião revelada, na medida em que é em seu seio que o si singular - que encarnou de fato a essência divina - pode tornar-se Espírito. Na verdade, segundo Hegel, é na comunidade que todos os dias ele morre para sua carne e ressuscita como Espírito. ${ }^{53}$ É na comunidade, portanto, que se exprimem tanto a memória do divino encarnado como o Espírito que o acompanhava. Agora, ela é o sinal daquilo que está além da morte do indivíduo singular: a consciênciade-si daquele si individual divinizado que se tornou universal, ou seja, o englobante espiritual que se reconhece como unido à essência universal. ${ }^{54}$

Ora, com a morte do divino encarnado se compreende também o decesso da própria essência absoluta: com isso a essência se transformou em sujeito, em espírito vital e universal da comunidade religiosa, que carrega em si a crença no Deus vivo após reconhecer universalmente a presença do Deus que se fez carne. É ela que explicita, por meio de suas representações, o movimento espiritual em que a essência universal vem a ser, e isto desde o seu estado abstrato - ao percorrer a determinação do si individual - até chegar ao si universal da consciência comunitária. ${ }^{55}$

Destarte, é nesta consciência religiosa que, de antemão, mesmo sob os aspectos da representação e da falta de algo no vir-a-ser conceitual, pode-se verificar aquilo que será expresso pelo puro conceito no Saber Absoluto: a reconciliação entre o sujeito e a sua essência, entre o si e o seu objeto. Neste estágio da religião, ressalta uma consciência religiosa que já possui para si a noção, mesmo contingente, do movimento do conceito que indica o em si que se sabe a si mesmo na autoconsciência de uma consciência-de-si.

Saliente-se, porém, que, mesmo que a consciência religiosa encontre na comunidade cristã uma forma eficaz de se unir à essencialidade universal, almejada e reconhecida como essencialidade de si mesma, a representação construída em torno deste conteúdo

\footnotetext{
${ }^{52}$ Cf. CALDAT, op. cit., 2013, p. 110.

${ }^{53}$ Cf. HEGEL, op. cit., v. 2., 1993, p. 203.

${ }^{54}$ Cf. CALDAT, op. cit., 2013, p. 110.

${ }^{55}$ Cf. ibid., p. 111.
} 
faz com que tal realidade seja ainda exterior e distante do si individual de cada sujeito. Existe inevitavelmente, segundo Hegel, um longe na consciência e a oposição de um além como obstáculo de sua plena realização. Sua reconciliação e unidade com a essência divina ou gira em torno de um longe no futuro, do Deus encarnado que voltará, ou de um longe no passado, de um si singular que encarnou a essência divina. Para a consciência religiosa, portanto, a reconciliação ainda não ocorreu de fato dentro de si mesma, ela se vê ainda dividida entre o bem e o mal, entre o finito e o infinito. Ela está sempre em seu coração como um amor eterno que se sente e se deposita num além, que ocorreu há muito tempo em seu mediador, ou que há de ocorrer em sua "segunda vinda", e nunca em seu presente imediato efetivo. ${ }^{56}$

Consequentemente, na religião revelada, o Absoluto ainda está sempre se evadindo e resistindo. Porém, seu momento é de grande relevância dentro da marcha do Espírito, que busca incessantemente fazer com que o Absoluto retorne refletido em si mesmo. Tal feito, ela já o realiza de forma contingente, pois apresenta ao homem a sua essência universal que se faz presente também em seu interior. Todavia, ela o incita e o estimula para que ele se aproxime cada vez mais dela...

\section{Referências}

CALDAT, Gilberto de Melo. A Religião na Fenomenologia do Espírito de Hegel. Florianópolis: Universidade Federal de Santa Catarina, 2013.

HEGEL, Georg Wilhelm Friedrich. Phänomenologie des Geistes. Werke 3. Frankfurt am Main: Suhrkamp, 1986.

HEGEL, Georg Wilhelm Friedrich. Frühe Schriften. Werke 1. Frankfurt am Main: Suhrkamp, 1986.

HEGEL, Georg Wilhelm Friedrich. Enzyklopädie der philosophischen Wissenschaften. Werke 10, III. Frankfurt am Main: Suhrkamp, 1986.

HEGEL, Georg Wilhelm Friedrich. Vorlesungen über die Philosophie der Religion. Werke 16, 17, I-II. Frankfurt am Main: Suhrkamp, 1986.

HEGEL, Georg Wilhelm Friedrich. Fenomenologia do Espírito. 2. ed. Petrópolis: Vozes, 1993. 2 v.

HYPPOLITE, Jean. Gênesis y estrutura de la Fenomenologia del Espíritu de Hegel. Barcelona: Península, 1974.

\footnotetext{
${ }^{56}$ Cf. HEGEL, op. cit., v. 2., 1993, p. 206.
} 
KOJÈVE, Alexandre. Introduction à la lecture de Hegel. Paris: Gallimard, 1947.

MENESES, Paulo. Para ler a Fenomenologia do Espírito. São Paulo: Loyola, 1985. 